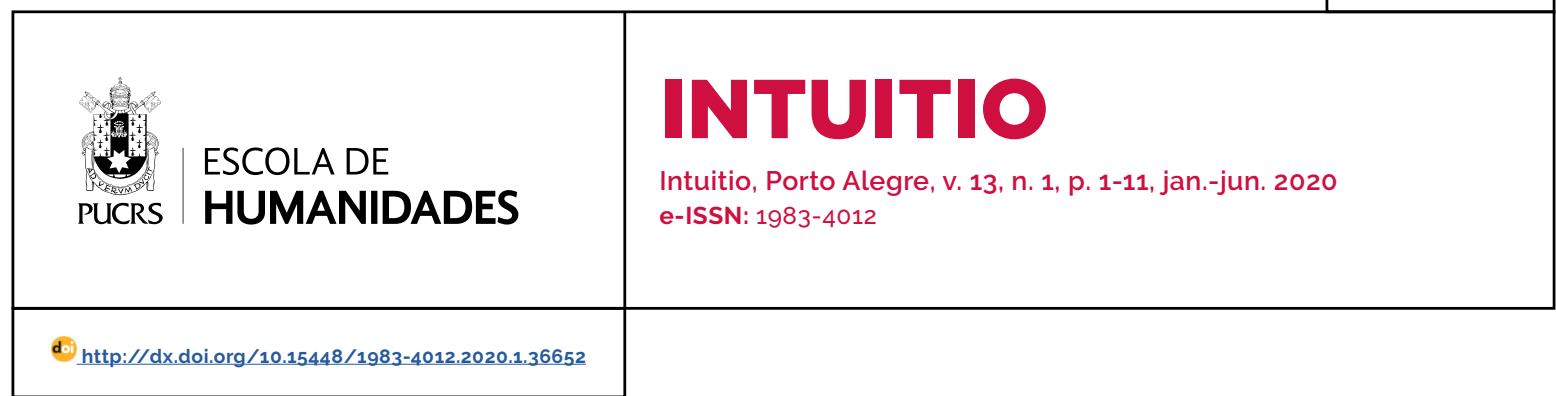

SEÇÃO: ARTIGO

\title{
Notas sobre o subsolo contrarrevolucionário de Budapeste
}

\author{
Notes about Budapest's counter-revolutionary subsoil
}

\author{
Marcus de Dutra \\ Mattos $^{1}$ \\ orcid.org/0000-0002-6009-4200 \\ marcus.mattos@acad.pucrs.br
}

Recebido em: 13 dez. 2019

Aprovado em: 14 jan. 2020

Publicado em: 27 jul. 2020

\section{(c) (i)}

Artigo está licenciado sob forma de uma licença Creative Commons Atribuição 4.0 Internacional.
Resumo: Fundada sobre a liberdade ontológica na obra O ser e o nada (1943), a psicanálise existencial tem o propósito de compreender o ser a partir de sua liberdade em situação. A obra Questões de método (1957), por sua vez, marca o periodo do pensamento satriano conhecido como "virada dialética". Essa mudança caracteriza-se fundamentalmente pela introdução de uma nova abordagem metodológica: o método progressivo-regressivo. Esse método almeja conflitar dialeticamente as totalizações históricas buscando a inteligibilidade do macrocosmo sociocultural. Essa virada ocorre em função da crise do pensamento marxista de sua época. Ao encravar o existencialismo no coração da filosofia marxista, e assim afirmar o marxismo enquanto filosofia insuperável de nosso tempo, Sartre aponta que o marxismo se tornou dogmático (crítica já presente na obra A transcendência do ego, de 1934) ao não partir da realidade material e dissociar teoria e prática. O famoso caso do metrô de Budapeste, relembrado por Sartre, aponta nessa direção: "o metrô de Budapeste era real na cabeça de Rákosi; se o subsolo da cidade não permitia sua construção era porque o subsolo era contrarrevolucionário". Na 2. ${ }^{a}$ tese sobre Feuerbach (1845), Marx já alerta: é na prática que o homem deve mostrar o caráter terreno de seu pensamento. Sartre repõe a questão entre subjetividade e objetividade, liberdade e História, acendendo-nos um farol que nos ilumina ainda hoje. Nosso estudo tem a intenção de mostrar a atualidade da critica sartriana ao materialismo dogmático, bem como a necessidade de partir do homem concreto e da materialidade, aqui e agora, para compreender, criticar e agir sobre a realidade histórica que nos circunda. Palavras-chave: Práxis. Materialismo Histórico. Questões de Método. Sartre.

\begin{abstract}
Founded on the ontological freedom in the work Being and Nothingness (1943), the existential psychoanalysis has the purpose to understand the being from its freedom in situation. The work Search for a method (1957), marks the period of Satrian thought known as the "dialectical turn." This change is fundamentally characterized by the introduction of a new methodological approach: the progressive-regressive method. This method seeks to conflict dialectically the historical totalizations aiming the intelligibility of the socio-cultural macrocosm. This turn is due to the crisis of Marxist thought of his time. By sticking to existentialism at the heart of Marxist philosophy and thus affirming Marxism as an insurmountable philosophy of our time, Sartre points out that Marxism has become dogmatic (a criticism already present in the work Transcendence of the Ego of 1934) by missing the material reality from the start and thus dissociate theory and practice. The famous case of the Budapest subway, recalled by Sartre, points in this direction: "Budapest subway was real in Rákosi's head; if the subsoil of the city did not permit its construction it was because the subsoil was counterrevolutionary ". In the 2nd thesis on Feuerbach (1845), Marx already warns: it is in practice that man must show the earthly character of his thought. Sartre restores the question between subjectivity and objectivity, freedom and history lighting a candle that illuminates us even today. Our study intends to show the relevance of Sartrian criticism to dogmatic materialism, as well as the need to depart from concrete man and materiality, here and now, to understand, criticize and act on the historical reality that surrounds us.
\end{abstract}

Keywords: Práxis. Historical Materialism. Search for a method. Sartre. 


\section{Introdução}

"Mas basta que um de nós, levado pela inquietação, se afaste da Ideia, que recuse o pensamento abstrato,

[...] que procure nas circunstâncias sempre singula-

res e datadas, unir-se com outros [...] para tornar um pouco menos injusto o reino da Injustiça e ele obrigará os outros a reinventar esse mesmo esforço tenaz [...]. Porque hoje há apenas duas maneiras de falar de si, a terceira pessoa do singular ou a primeira do plural. É necessário saber dizer 'nós' para dizer 'eu': é um fato incontestável. [...] os vampiros fizeram uma carnificina memorável, esmagaram a esperança; é necessário a cada um de nós retomar o fôlego, .... recomeçar tudo, inventar uma esperança morta, tentar viver".

(SARTRE. J-P. Situações IV)

Em 1957, Sartre é convidado por uma revista polonesa para escrever sobre a situação do existencialismo. Nessa época, influenciado por Henry Lefebvre e a crise do pensamento marxista, Sartre propõe um novo método, o progressivoregressivo, em um texto intitulado "Existencialismo e Marxismo". O objetivo sartreano é claro: propor uma antropologia estrutural e histórica. O título inicial é trocado por "Questões de método" e, logo depois, é anexado à obra Crítica da razão dialética (1960). Essa é a "virada dialética" na trajetória sartriana, da qual se inicia com uma reflexão acerca das diferenças entre o existencialismo e o marxismo e, mais importante que isso, seus pontos de convergência.

Sartre tece comentários sobre as inferências de Lukács acerca de seu existencialismo. É bem verdade, como lembra Mészáros, ${ }^{2}$ que Sartre se arrependeria do tom usado nesse texto ao se referir sobre Lukács. Porém, e aqui se encontra o cerne de nosso escrito, esse debate entre Sartre e Lukács acerca dos limites, acertos e erros do marxismo, bem como da tensão entre o sujeito e as estruturas objetivas, é uma discussão central que nos parece estar viva ainda hoje, ${ }^{3}$ se estivermos dispostos a elaborar uma resposta à pergunta sartriana sobre o que se pode saber de um homem. Propor uma antropologia estrutural e histórica é isto: maestrar a impossibilidade aparente de uma fusão entre o pensamento que descreve o sujeito em sua situação concreta, o existencialismo, a fenomenologia ontológica; e o pensamento que desvela a estrutura, o macrocosmo social que circunda esse indivíduo fenomenológico.

A vivacidade dessa proposta mostra-se pela forma da crítica sartriana ao marxismo de sua época. Sartre critica o marxismo por ter estagnado e essa estagnação não é mais do que o resultado de uma complicada sintese do caminho adotado pela URSS. Ao término de nosso escrito, perceberemos que a crítica sartriana ao marxismo não se dá ao pensamento de Marx em si; outrossim, seu foco é a forma concreta e material empregada na temporalidade que Ihe pertencia. Este "materialismo metafísico"4 ocorreu exatamente porque vários textos originais de Marx, como a A ideologia alemã, ficaram ou inéditos (até 1932) ou obscurecidos pela URSS. Esse é o cerne da confusão acerca do conceito de ideologia (desde a Segunda Internacional) tão amplamente usado, inclusive por Lukács, no espectro marxista. Nesse sentido, essa busca por unir a vivência primeira do ser fenomênico à estrutura objetiva não será, como veremos, uma tarefa impossivel. Sartre busca alertar-nos da existência de um Marx que fora inutilizado

\footnotetext{
MÉSZÁROS, I. A obra de Sartre. Trad. Rogério Bettoni. São Paulo: Boitempo, 2012. p.225-6.

3 MATTOS, M. D. Sartre e Lukács: Notas para um acerto de contas. In: CASTRO, Fabio Caprio Leite de; NORBERTO, M. S. (Orgs). Sartre Hoje: v. 1. Porto Alegre: Fi, 2017. p. 189-206.

4 "Os teóricos de extrema-esquerda acusaram algumas vezes a fenomenologia de ser um idealismo e de afogar a realidade na maré das ideias. Mas se o idealismo é a filosofia sem mal de M. Brunschvicg, se é uma filosofia em que o esforço de assimilação espiritual não se depara jamais com resistências exteriores, em que o sofrimento, a fome, a guerra se diluem em um lento processo de unificação das ideias, então nada é mais injusto do que chamar os fenomenólogos de idealistas. Pelo contrário, há séculos que não se sentia na filosofia uma corrente tão realista. Eles recolocaram o homem no mundo, devolveram o devido peso a suas angústias e seus sofrimentos, e também a suas revoltas. Infelizmente, enquanto o Eu continuar sendo uma estrutura da consciência absoluta, poder-se-á censurar a fenomenologia por ser uma "doutrina escapista", por puxar uma parcela do homem para fora do mundo e desviar desse modo a atenção dos verdadeiros problemas. Parece-nos que essa crítica não tem mais razão de ser ao fazermos do Moi um existente rigorosamente contemporâneo do mundo e cuja existência tem as mesmas características essenciais que o mundo. Sempre me pareceu que uma hipótese de trabalho tão fecunda como o materialismo histórico não requeria absolutamente como fundamento essa absurdidade que é o materialismo metafísico. Não é, de fato, necessário que o objeto preceda o sujeito para que os pseudovalores espirituais se desvaneçam e para que a moral reencontre suas bases na realidade. Basta que o Moi seja contemporâneo do Mundo e que a dualidade sujeito-objeto, que é puramente lógica, desapareça definitivamente das preocupações filosóficas. O Mundo não criou o Moi, o Moi não criou o Mundo; são dois objetos para a consciência absoluta, impessoal, e é por ela que eles se acham ligados". SARTRE, J.-P. A transcendência do Ego. Lisboa: Colibri, 1994. p. 70.
} 
e pouco, ou nada, teria a ver com os erros e os resultados da crise marxista no século $X X$

Ainda hoje, essa leitura mostra-se como uma proficua possibilidade metodológica para o desvelamento do real e para o que Sartre e Marx realmente almejaram: agir na matéria, ou, como lembra Sartre, descobrir o mundo. O real é a história; cabe-nos compreender seu movimento dialético e, acima de tudo, agir sobre ela. Para isso, o primeiro passo metodológico será compreendê-la a partir da vivência concreta e individual de cada sujeito para, logo depois, partirmos para sua etapa estrutural e objetiva. Esse vaivém satriano é a configuração nodal de seu método progressivo-regressivo. Dito de outra forma, é preciso compreender o ser humano de ponta a ponta e extrair desse movimento dialético a sintese necessária para a ação efetiva.

\section{Marxismo e existencialismo}

Toda a filosofia é prática. Assim inicia a virada dialética sartriana no livro Questões de método. 0 objetivo de Sartre é, ao mesmo tempo, demonstrar a impossibilidade de um pensamento filosófico desarraigado da materialidade histórica e a possivel incompreensão desse movimento por parte daqueles que Sartre intitularia "ideólogos". É nesse sentido que Sartre mostra que mesmo o método do racionalismo analítico serviu, por um lado, de arcabouço para a burguesia em seu intuito de solapar o Antigo Regime, bem como de base ao pensamento liberal e sua doutrina de atomização do proletariado. ${ }^{5}$

Assim, Sartre define três grandes momentos da filosofia moderna ocidental e sua insuperabilidade enquanto seu momento histórico não houver sido ultrapassado. Esses momentos filosóficos, de
Descartes e de Locke, o de Kant e de Hegel e, finalmente, o de Marx, ${ }^{6}$ não se sustentarão apenas pela "consciência de si"; outrossim, perdurarão enquanto expressão ideal da realidade histórica vigente. Aqui, Sartre insemina no âmago de toda a filosofia aquilo que aparentemente lhe é externa: o movimento real da História. Esta é a grande tensão que Sartre se propõe a operar: não será a filosofia que fará a história, tampouco lhe será objeto. Sartre toma partido pelo pensamento marxiano em sua defesa contra Hegel acerca da forma efetiva que a alienação opera, bem como sua necessidade de se objetificar: esse é o momento de uma autocontemplação em um mundo que esse sujeito mesmo criou.

\begin{abstract}
Nenhuma prestidigitação dialética consegue tirar dai a alienação; é porque não se trata de umjogo de conceitos, mas da História real: "Na produção social de sua existência, os homens entram em relações determinadas, necessárias, independentes de sua vontade; essas relações de produção correspondem a um grau de determinado desenvolvimento de suas forças produtivas materiais; 0 conjunto dessas relações de produção constitui a base real sobre a qual se ergue uma superestrutura jurídica e politica e à qual correspondem determinadas formas de consciência social"?
\end{abstract}

A realidade histórica descrita e vivida por Sartre apresenta-se exatamente por esse conflito entre relações determinadas: algo que ocorria no final da década de 1950, a saber, o trabalho, a ação alienada na matéria, estavam na origem do bloqueio da possibilidade de reconhecermonos no produto de nosso trabalho. Logo, não será a "consciência de si" que aniquilará esse movimento alienante e possibilitará a livre produção do trabalho criador. É necessária a ação de uma práxis revolucionária. ${ }^{8}$ Esse é o âmago da

\footnotetext{
5 "Toda filosofia é prática, inclusive aquela que, à primeira vista, parece a mais contemplativa; o método é uma arma social e política: o racionalismo analítico e crítico de grandes cartesianos lhes sobreviveu; nascido da luta, voltou-se sobre ela para iluminá-la; no momento em que a burguesia empreendia a sabotagem das instituições do Antigo Regime, ele atacava as significações ultrapassadas que tentavam justificá-las. Mais tarde, esteve a serviço do liberalismo e dotou de uma doutrina as operações que tentavam realizar a 'atomização' do proletariado". SARTRE, J.-P. Crítica da Razão Dialética. Trad. Guilherme João de Freitas Teixeira. Rio de Janeiro: DP\&A, 2002. p. 20.

6 "Existe o 'momento' de Descartes e de Locke, o de Kant e de Hegel e, por fim, o de Marx. Essas três filosofias tornam-se, cada uma por sua vez, o húmus de todo o pensamento particular e o horizonte de toda a cultura, elas são insuperáveis enquanto o momento histórico de que são a expressão não tiver sido superado". SARTRE, J.-P. Crítica da Razão Dialética. Trad. Guilherme João de Freitas Teixeira. Rio de Janeiro: DP\&A, 2002. p. 21.

7 SARTRE, J.-P. Crítica da Razão Dialética. Trad. Guilherme João de Freitas Teixeira. Rio de Janeiro: DP\&A, 2002. p. 25.

8 "I...] para que os homens dela se liberem e para que seu trabalho se tome a pura objetivação de si mesmos, não é suficiente 'que a consciência se pense a si mesma', mas são necessários o trabalho material e a práxis revolucionária: quando Marx escreve: 'Do mesmo modo que não se julga um individuo a partir da ideia que tem de si mesmo, assim também não se pode julgar uma... época de agitação revolucionária a partir de sua consciência de si', ele assinala a prioridade da ação (trabalho e práxis social) sobre o Saber, assim como sua heterogeneidade". SARTRE, J.-P. Crítica da Razão Dialética. Trad. Guilherme João de Freitas Teixeira. Rio de Janeiro: DP\&A, 2002. p. 25.
} 
diferenciação entre Ação e Saber proposta por Marx e subscrita por Sartre. Nesse sentido, Sartre busca nos alertar para a irredutibilidade do fato humano ao conhecimento, uma vez que esse fato deve ser vivido, produzido. Dito de outro modo: a possibilidade de reconhecer-se no trabalho - e, assim, romper com a alienação da criação - não depende da capacidade subjetiva da tomada de consciência desse movimento. Podemos perceber esse fato operando em nossas vidas e, essa tomada de consciência, não significará por si a garantia de mudança da relação material; visto que estamos todos presos pela lógica da escassez, como veremos.

É partindo da irredutibilidade do fato humano ao conceito e, ao mesmo tempo, sua dependência visceral ao movimento histórico que Sartre afirma: "Marx tem razão, simultaneamente, contra Kierkegaard e contra Hegel, uma vez que afirma, com o primeiro, a especificidade da existência humana, e uma vez que toma, com o segundo, o homem concreto em sua realidade objetiva". 9 Sartre descreve esse movimento histórico em sua própria história ao relembrar Marx: "as ideias da classe dominante são, em cada época, as ideias dominantes". ${ }^{\circ}$ Se, por um lado, era-lhe ensinado com rigor a lógica aristotélica e a linguística, por outro, "o horror da dialética era tal visto que o próprio Hegel era [...] um desconhecido". ${ }^{11}$ Nessa perspectiva, e concretizando a frase marxista, Sartre afirma que a leitura das obras $A$ ideologia alemã e O capital não mudaram o âmago de seu ser. Foi a guerra, o movimento do operariado, a alienação, os afluxos e refluxos da Histórica concreta que fizeram Sartre compreender de fato o peso e a potência do pensamento marxiano.

Assim, o marxismo como "filosofia tornada mundo" arrancava-nos à cultura defunta de uma burguesia que vegetava a partir de seu passado; tomávamos, às cegas, a via perigosa de um realismo pluralista que visava o homem e as coisas em sua existência "concreta". No entanto, permaneciamos nos limites das "ideias dominantes": o homem que desejávamos conhecer em sua vida real, ainda não tínhamos a ideia de considerá-lo, antes de tudo, como um trabalhador que produz as condições de sua vida. Durante muito tempo, confundimos o total com o individual; o pluralismo - que nos tinha servido tão bem contra o idealismo de Brunschvicg - impediu-nos de compreender a totalização dialética; divertíamo-nos em descrever essências e tipos artificialmente isolados, em vez de reconstituir o movimento sintético de uma verdade "devinda". Os acontecimentos políticos levaram-nos a utilizar como uma espécie de grade, mais cômoda do que verídica, o esquema de "luta de classes": mas foi necessária toda a história sangrenta desse meio século para levar-nos a apreender sua realidade e para situar-nos em uma sociedade dilacerada. Foi a guerra que fez explodir os enquadramentos envelhecidos de nosso pensamento. A guerra, a Ocupação, a Resistência, os anos seguintes. Desejávamos lutar ao lado da classe operária, compreendiamos, enfim, que o concreto é história e a ação é dialética. Tínhamos renegado o realismo pluralista por tê-lo reencontrado entre os fascistas e descobriamos o mundo.12

Como vemos, Sartre descreve-se e inscrevese na tradição marxiana. Por outro lado, o que impediu Sartre de abandonar por completo o existencialismo, a fenomenologia ontológica, foi o fato de que o marxismo havia parado: a separação operada pela URSS entre teoria e prática (e replicada por Lukács ao conceitualizar um a priori em seu livro Existentialisme et Marxisme), nas palavras de Sartre, não é mais do que efeito de "uma verdadeira cisão que colocou a teoria de um lado e a práxis do outro". ${ }^{13}$ Sartre responde à Lukács exatamente para delimitar e justificar sua coerência junto ao pensamento marxista em sua filosofia existencial: "estávamos convencidos ao mesmo tempo de que o materialismo histórico fornecia a única interpretação válida da História e de que o existencialismo permanecia a única abordagem concreta da realidade". ${ }^{14}$ Por esse motivo, "o pensamento concreto deve nascer da práxis e voltar-se sobre ela para iluminá-la".15

\footnotetext{
SARTRE, J.-P. Crítica da Razão Dialética. Trad. Guilherme João de Freitas Teixeira. Rio de Janeiro: DP\&A, 2002. p. 26.

MARX, Karl. A ideologia alemã: critica da mais recente filosofia alemã em seus representantes Feuerbach, B. Bauer e Stirner, e do socialismo alemão em seus diferentes profetas. São Paulo: Boitempo, 2007. p. 47.

${ }_{11}$ SARTRE, J.-P. Crítica da Razão Dialética. Trad. Guilherme João de Freitas Teixeira. Rio de Janeiro: DP\&A, 2002. p. 28.

12 SARTRE, J.-P. Crítica da Razão Dialética. Trad. Guilherme João de Freitas Teixeira. Rio de Janeiro: DP\&A, 2002. p. 29-30.

13 SARTRE, J.-P. Crítica da Razão Dialética. Trad. Guilherme João de Freitas Teixeira. Rio de Janeiro: DP\&A, 2002. p. 31.

14 SARTRE, J.-P. Crítica da Razão Dialética. Trad. Guilherme João de Freitas Teixeira. Rio de Janeiro: DP\&A, 2002. p. 30.

15 SARTRE, J.-P. Crítica da Razão Dialética. Trad. Guilherme João de Freitas Teixeira. Rio de Janeiro: DP\&A, 2002. p. 31.
} 
Esse é o seio da crítica sartriana ao marxismo aplicado na URSS. A burocracia, o velamento, os mandos verticais estabelecidos no partido, todas essas criticas - impossiveis de serem feitas com eficácia dentro do regime que Lukács estava inserido - são o resultado fino de uma cisão entre teoria e prática para Sartre; de um engessamento teórico que estabeleceu, aprioristicamente, conceitos metafísicos estanques e definiu burgueses e proletários antes de compreender sua existência real. ${ }^{16}$ Percebe-se que Sartre, como foi dito, assume o marxismo como a única interpretação válida da História e, nesse sentido, sua crítica não se dá na intenção de destruir ou renegar o pensamento marxista. Outrossim, sua investida acontece de ponta a ponta para reerguer esse pensamento que the possibilitou descobrir o mundo.

O metrô de Budapeste era real na cabeça de Rákosi; se o subsolo da cidade não permitia sua construção é porque esse subsolo era contra-revolucionário. O marxismo, enquanto interpretação filosófica do homem e da História, devia necessariamente refletir as opiniões preconcebidas do planejamento: essa imagem fixa do idealismo e da violência exerceu sobre os fatos uma violência idealista. Durante anos, o intelectual marxista julgou que servia a seu partido, violando a experiência, negligenciando os detalhes incômodos, simplificando grosseiramente os dados e, sobretudo, conceitualizando o acontecimento antes de tê-lo estudado. ${ }^{17}$

A tentativa de limitar a existência ao conceito aprioristicamente, ao apressar-se em determinar, enquadrar, encaixar o ser humano em um conceito que pode não condizer com a realidade é, por um lado, o que Marx chama de "economicismo". "O marxismo concreto deve analisar de forma profunda os homens reais e não os dissolver em um banho de ácido sulfúrico" ${ }^{18} \mathrm{O}$ risco corrido por essas tentativas apressadas de totalização é a perda da compreensão do movimento real da História. É um erro, nas palavras de Sartre, das quais subscrevemos, substituir grupos reais por coletividades indeterminadas. ${ }^{19}$

Não há, aqui, uma defesa do abandono dos conceitos, uma abertura ao relativismo ou uma crítica meta-narrativa. Outrossim, Sartre defende algo que é dramaticamente vivo hoje: a necessidade de partir do sujeito concreto, em sua vivência e ação concreta para criar e confirmar o seu conceito. Por esse motivo, a totalização proposta por Sartre implica um duplo serviço: descrever detalhadamente o sujeito, o ser em sua concretude e cruzá-lo com as estruturas objetivas que o circundam. A síntese dialética deve surgir desse duplo serviço. É verdade, por outro lado, que essa proposta dificulta e complexifica a compreensão do movimento da História; porém, se alguma dessas etapas forem apressadas de mais (ou até negligenciadas), corremos o risco certo de errarmos na análise e, por consequência, erraremos na ação.

Portanto, a tentativa sartriana de reconstrução ou refundação do pensamento marxista levado à prática perpassa uma crítica que não é endereçada necessariamente à Marx, mas ao seu uso. Por isso, Sartre pode defender que o existencialismo e o

16 "Quando estuda, por exemplo, a breve e trágica história da República de 1848, ele não se limita - como seria feito atualmente - a declarar que a pequena burguesia republicana traiu o proletariado, seu aliado. Pelo contrário, tenta apresentar essa tragédia no detalhe e no conjunto. Se subordina os fatos anedóticos à totalidade (de um movimento, de uma atitude), é através deles que pretende descobri-la. Ou por outras palavras, dá a cada acontecimento, além de sua significação particular, um papel de revelador: uma vez que o princípio que preside a pesquisa é o de procurar o conjunto sintético, cada fato, uma vez estabelecido, é interrogado e decifrado como parte de um todo; é sobre ele, pelo estudo de suas carências e de suas 'sobre-significações' que se determina, a título de hipótese, a totalidade no seio da qual voltará a encontrar sua verdade. Assim, o marxismo vivo é heurístico: em relação à sua pesquisa concreta, seus princípios e seu saber anterior aparecem como reguladores". SARTRE, J.-P. Crítica da Razão Dialética. Trad. Guilherme João de Freitas Teixeira. Rio de Janeiro: DP\&A, 2002. p. 33

17 SARTRE, J.-P. Crítica da Razão Dialética. Trad. Guilherme João de Freitas Teixeira. Rio de Janeiro: DP\&A, 2002. p. 31.

18 "[...] o marxismo concreto deve analisar de forma profunda os homens reais e não os dissolver em um banho de ácido sulfúrico. Ora, a explicação rápida e esquemática da guerra como operação da burguesia comerciante faz desaparecer esses homens que conhecemos bem - Brissot, Guadet, Gensonné, Vergniaud - ou os constitui, em última análise, como os instrumentos puramente passivos de sua classe". SARTRE, J.-P. Critica da Razão Dialética. Trad. Guilherme João de Freitas Teixeira. Rio de Janeiro: DP\&A, 2002. p. 46.

19 "E também que é necessário evitar, a qualquer preço, substituir os grupos reais e perfeitamente definidos (a Gironda) por coletividades insuficientemente determinadas (a burguesia dos importadores e exportadores). Os girondinos existiram, perseguiram objetivos definidos, fizeram a História em uma situação bem determinada e na base de condições exteriores: julgavam escamotear a Revolução em seu benefício; de fato, acabaram por radicalizá-la e democratizá-la. É no interior dessa contradição política que se deve compreendê-los e explicá-los". SARTRE, J.-P. Crítica da Razão Dialética. Trad. Guilherme João de Freitas Teixeira. Rio de Janeiro: DP\&A, 2002. p. 47. 
marxismo buscam o mesmo objeto; 20 porém, o uso errôneo do pensamento marxista reabsorveu o homem na ideia, a existência real no conceito a priori. Isso nada tem a ver com a densidade do pensamento marxista visto que, para Sartre, vivemos o tempo da filosofia de Marx e essa é, hoje, "[...] uma evidência insuperável enquanto as transformações das relações sociais e os progressos da técnica não tiverem libertado o homem do jugo da escassez". ${ }^{21}$

As sinteses concretas só podem existir em uma dialética em movimento, em uma totalização incessante que coloca a verdade no devir, ${ }^{22}$ visto que a condição que torna a filosofia marxiana insuperável em nosso tempo é a categoria de escassez. É verdade, por um lado, que o modo de produção determina o desenvolvimento da vida social; porém, isso não se dá de forma inata e atemporal. Esse processo opera e conservase de forma alienante hoje porque agimos e produzimos sob o julgo da escassez, que resulta no estranhamento entre criador e criatura na vida material. Tal dialética inerte é a "pré-história" referida por Marx da qual Sartre subscreve ao defender que, neste mundo de alienação, não podemos sequer conceber o que seria o reino da liberdade. Somos produtos e produtores deste mundo pautado pela escassez; nosso trabalho é alienado de nós mesmos e esse ciclo inerte nos aprisiona. Será somente quando essa lógica material tiver sido ultrapassada que o pensamento marxista desaparecerá e dará lugar à uma filosofia da liberdade concreta. ${ }^{23}$

Para a compreensão do movimento das relações concretas entre os indivíduos, Sartre propõe o método progressivo-regressivo: fórmula de comparação e de confrontação dialética entre o singular e o universal, o particular e o coletivo na História, partindo do ser e chegando à estrutura. É no pensamento de Henry Lefebvre que Sartre busca essa inspiração:

Lefebvre começa por observar que a realidade camponesa se apresenta, antes de tudo, com uma complexidade horizontal: trata-se de um grupo humano de posse de técnicas e de uma produtividade agricola definida, em relação com essas técnicas, com a estrutura social que elas determinam e que volta sobre elas para condicioná-las. Esse grupo humano, cujos caracteres dependem, amplamente, dos grandes conjuntos nacionais e mundiais (que, por exemplo, condicionam as especializações em escala nacional), apresenta uma multiplicidade de aspectos que devem ser descritos e fixados (aspectos demográficos, estrutura familiar, habitat, religião etc.). Mas Lefebvre apressa-se em acrescentar que essa complexidade horizontal é acompanhada por uma "complexidade vertical" ou "histórica": com efeito, no mundo rural, é possivel identificar a "coexistência de formações de idade e de data diferentes". As duas complexidades "reagem uma na outra". ${ }^{24}$

É bem verdade, por outro lado, que Henry Lefevbre adverte sobre seu método não ter sido intencionado para incorporar o existencialismo

\footnotetext{
20 "Hoje, a experiência social e histórica escapa do Saber. Os conceitos burgueses não se renovam e se desgastam rapidamente; os que permanecem carecem de fundamento: as aquisições reais da sociologia americana não podem dissimular sua incerteza teórica; após um começo fulminante, a psicanálise cristalizou-se. Os conhecimentos de detalhe são numerosos, mas falta a base. Quanto ao marxismo, tem fundamentos teóricos, abrange toda a atividade humana, mas não sabe mais nada: seus conceitos são diktats; seu objetivo já não é o de adquirir conhecimentos, mas o de constituir-se a priori em Saber absoluto. Diante dessa dupla ignorância, o existencialismo conseguiu renascer e se manter porque reafirmava a realidade dos homens, como Kierkegaard afirmava contra Hegel sua própria realidade. No entanto, o dinamarquês recusava a concepção hegeliana do homem e do real. Pelo contrário, existencialismo e marxismo visam o mesmo objeto, mas o segundo reabsorveu o homem na ideia, enquanto o primeiro o procura por toda parte onde ele está, em seu trabalho, em sua casa, na rua". SARTRE, J.-P. Crítica da Razão Dialética. Trad. Guilherme João de Freitas Teixeira. Rio de Janeiro: DP\&A, 2002. p. 34-35. ${ }_{21}$ SARTRE, J.-P. Crítica da Razão Dialética. Trad. Guilherme João de Freitas Teixeira. Rio de Janeiro: DP\&A, 2002. p. 38-39.

22 "Do mesmo modo que o marxismo, o existencialismo aborda a experiência para nela descobrir sínteses concretas; só pode conceber essas sinteses no interior de uma totalização em movimento e dialética que nada mais é do que a própria História ou — do ponto de vista estritamente cultural em que nos situamos aqui - do que o "devir-mundo-da-filosofia". Para nós, a verdade toma-se, ela é e será devinda. Trata-se de uma totalização que se totaliza incessantemente; os fatos particulares não significam nada, não são verdadeiros ou falsos enquanto não forem referidos pela mediação de diferentes totalidades parciais à totalização em andamento". SARTRE, J.-P. Critica da Razão Dialética. Trad. Guilherme João de Freitas Teixeira. Rio de Janeiro: DP\&A, 2002. p. 36

${ }_{23}$ "Mas a proposição de Marx parece-me uma evidência insuperável enquanto as transformações das relações sociais e os progressos da técnica não tiverem libertado o homem do jugo da escassez. É bem conhecido o trecho de Marx que faz alusão a essa época longinqua: 'De fato, esse reino da liberdade começa apenas onde cessa o trabalho imposto pela necessidade e pela finalidade exterior; esse momento encontra-se, portanto, para além da esfera da produção material propriamente dita' (Das Kapital, III, p. 873). Logo que existir. para todos, uma margem de liberdade real para além da produção da vida, o marxismo desaparecerá; seu lugar será ocupado por uma filosofia da liberdade. Mas estamos desprovidos de qualquer meio, de qualquer instrumento intelectual ou de qualquer experiência concreta que nos permita conceber essa liberdade ou essa filosofia". SARTRE, J.-P. Crítica da Razão Dialética. Trad. Guilherme João de Freitas Teixeira. Rio de Janeiro: DP\&A, 2002. p. 38-39.

24 SARTRE, J.-P. Crítica da Razão Dialética. Tradução de Guilherme João de Freitas Teixeira. Rio de Janeiro: DP\&A, 2002. p. 51.
} 
sartriano ${ }^{25}$ em seu bojo conceitual que é puramente marxista. Sartre, por sua vez, busca a inspiração em Lefebvre para essa confrontação entre complexidades "horizontais e verticais" no sentido de efetivar a incorporação de "disciplinas auxiliares" - a sociologia e a psicanálise para a inteligibilidade histórica arraigada em sua psicanálise existencial. Cabe dizer dessa afirmação de Lefrebvre, acerca do conteúdo inteiramente marxista de seu método regressivoprogressivo, que ela reforça nossa suspeita acerca da obra sartriana dita "endereçada à burguesia" (como O idiota da família) ser, ela também, de ponta a ponta, marxista: Sartre afirma que $O$ idiota da familia é a continuação de Questões de método, ${ }^{26}$ parte desta obra para aplicar e incorporar a sociologia e a psicanálise ao esforço de compreensão da tensão entre o singular e o universal, a vivência e a História, desde a infância de Gustave Flaubert na intenção construir uma antropologia estrutural e histórica.

\section{Sobre as disciplinas auxiliantes e o método progressivo-regressivo}

Sartre reforça que um dos grandes erros marxistas de seu tempo é o de não englobar, em sua totalidade, a infância na totalização histórica. Dito de outro modo: é bem possivel que se conceitue o bebê Flaubert como um bebê burguês, visto que nasceu no seio de uma familia de posses, sua mãe carregava rastros de "sangue azul" e seu pai, por outro lado, era médico renomado. Essa afirmação não é falsa; porém, esquece-se aqui o principal objeto para a verdadeira compreensão da vida de Flaubert: ele vivenciou essas determinações estruturais e constituiu-se na relação com essa objetividade. Por esse ângulo, conseguimos entender que "é a infância que modela preconceitos insuperáveis".27 Por consequência, a tentativa de descrição acerca da vida de alguém apenas sob o escopo objetivo, estrutural, "externo ao ser", por assim dizer, tende ao erro: ele exige ser estudado a um só tempo pelas duas pontas.

Se não percebermos que é pela maneira com a qual a infância é vivenciada, com toda a sua singularidade, não entenderemos o motivo pelo qual Baudelaire via-se preso à mãe, e Flaubert, ao pai. Ambos foram crianças burguesas ${ }^{28}$ e tornaramse escritores burgueses; porém, se rotulados a priori de "burgueses" e, assim, dissolvidos em "ácido sulfúrico", perderemos a capacidade de compreender suas dramáticas diferenciações. Baudelaire não é Flaubert e não é qualquer criança burguesa na França do século XIX que teve plenas condições de ser um grande escritor. Dito de outra forma, não somos só nossa classe. A psicanálise será a grande disciplina auxiliadora nessa etapa de interiorização da exterioridade:

\footnotetext{
25 "Jean.Paul Sartre ha decidido en su Critique de la raison dialectique tomar uno de los articulas aqui reproducidos (dedicado, concreta aunque modestamente, a las cuestiones campesinas y la sociología rural) como primer modelo (metodológio) de un proceder 'progressivo-regresivo', que integra la sociología y la historia en una perspectiva dialéctica. Desde aqui le damos las gracias, pero que el lector eventual (benévolo o malévolo) no vea en ello ninguna prueba, ningún signo de una identidad o siquiera de una analogia entre el recorrido aquí jalonado y el de la filosofía del existencialismo. El trayecto que va de la filosofía a la metafilosofía no puede acercarse al de un filósofo, por eminente que sea, que mantiene y perfecciona, mientras anda camino, categorias filosóficas. El texto citado por Jean.Paul Sartre es por desgracia de masiado breve. Data de una época en la cual por todas partes (tanto por el lado 'capitalista' como por el lado 'socialista' y 'comunista') se ejercía un terrorismo implacable. Para eludir la presión, no había otra alternativa: que prolongar el pensamiento de Marx sin citar la fuente. ¿Proceder analítica-regresivo?: Es el precepto formulado por Marx cuando declara que el hombre esclarece al mono, y el adulto al niño; que lo actual permite comprender lo pasadu y la sociedad capitalista las anteriores sociedades, porque desarrolla las categorias esenciales de éstas. Así, la renta de la tierra capitalista permite comprender la renta feudal, las rentas del sudo en la Antigüedad, etcétera". LEFEBVRE, Henri. De lo rural a lo urbano. 4. ed. Barcelona: Península, 1978. p. 16-17.

26 "Afinal um homem nunca é um individuo; seria melhor chamá-lo de universal singular: totalizado e, por isso mesmo, universalizado por sua época, ele a retotaliza ao reproduzir-se nela como singularidade. Universal pela universalidade singular da história humana, singular pela singularidade de seus projetos, ele exige ser estudado a um só tempo pelas duas pontas. Precisamos encontrar um método apropriado. Apresentei os principios de um em 1958 e não repetirei o que disse então: prefiro mostrar, sempre que necessário, como ele se faz no próprio trabalho para obedecer às exigências de seu objeto". SARTRE. J.-P. O idiota da familia. Trad. Julia da Rosa Simões. Porto Alegre: L\&PM, 2013. p. 7. v. 1.

${ }_{27}$ "[...] é a infância que modela preconceitos insuperáveis, é ela que leva a sentir profundamente, nas violências do adestramento e no desvario do animal adestrado, a pertinência ao meio como um acontecimento singular. Atualmente, só a psicanálise permite estudar a fundo o processo pelo qual uma criança, no escuro, às apalpadelas, vai tentar representar, sem o compreender, a personagem social que os adultos the impõem, é ela sozinha que nos mostrará se tal personagem sufoca no desempenho de seu papel, se procura evadir-se dele ou se o assimila inteiramente". SARTRE, J.-P. Crítica da Razão Dialética. Trad. Guilherme João de Freitas Teixeira. Rio de Janeiro: DP\&A, 2002. p. 57. 28 "Os marxistas de hoje apenas se preocupam com os adultos: ao lê-los, seriamos levados a acreditar que nascemos na idade em que ganhamos nosso primeiro salário; esqueceram sua própria infância e, ao lê-los, tudo se passa como se os homens experimentassem sua alienação e reificação, antes de tudo, no seu próprio trabalho quando, afinal, cada um a vive, antes de tudo, como criança, no trabalho de seus pais". SARTRE, J.-P. Crítica da Razão Dialética. Trad. Guilherme João de Freitas Teixeira. Rio de Janeiro: DP\&A, 2002. p. 58.
} 
Mas tenhamos cuidado com o seguinte: cada um vive os primeiros anos no desvario ou ofuscamento como uma realidade profunda e solitária: a interiorização da exterioridade é, aqui, um fato irredutivel. [...] No interior de uma totalização dialética, a psicanálise remete, por um lado, às estruturas objetivas e às condições materiais; por outro, à ação da nossa insuperável infância em relação à nossa vida de adulto. Daqui em diante, torna-se impossivel ligar diretamente Madame Bovary à estrutura político-social e à evolução da pequena burguesia; será necessário relacionar a obra com a realidade presente tal como é vivida por Flaubert, através de sua infância. ${ }^{29}$

\section{A crítica sartriana percorre o caminho da busca} por (re)colocar o homem no centro do marxismo. Se novas disciplinas são necessárias, isso ocorre exatamente porque o marxismo parou; tornouse um "materialismo metafísico", 30 esqueceuse que Marx elaborara seus conceitos acerca da burguesia e do proletariado, dominantes e dominados, a partir do estudo de dados concretos, de relações sociais concretas; ou, dito de outra forma, sua teoria é a apreensão ideal do movimento real do objeto. Nesse sentido, pouco ou nada ajudará a compreensão se dissermos que "Napoleão era um acidente", que ele foi um objeto de uso para a burguesia francesa liquidar a Revolução. Perde-se a capacidade de perceber que este Napoleão era necessário porque vivenciou esse conflito de classes, sua postura autoritária e seus mandos e desmandos não foram acasos, contingências: foram o resultado fino de uma concatenação entre o ser Napoleão e a estrutura social que lhe circundava. Será nula a máxima de Engels ${ }^{31}$ retomada por Sartre de que "são os próprios homens que fazem sua história, mas em determinado meio que os condiciona" (tradução nossa) ${ }^{32}$ se não produzirmos conceitos que nos propiciem a captura desse movimento do real a partir de sua expressão, e não o seu contrário: tentar captar o movimento no presente com conceitos apriorísticos que, por sua vez, foram forjados para expressar o real que era de seu tempo. Em síntese, a preocupação sartriana - que é a de Marx - é a de captar o movimento do real a partir do real, construir o método a partir desse movimento para compreendê-lo; enfim: esquecer o materialismo metafísico, isto é, aderir ao marxismo de fato, o materialismo histórico.

O que é o marxismo senão a união entre um método, uma crítica da economia política e uma teoria da revolução? Nesse sentido, Sartre acertou ao criticar o "marxismo" vigente em sua época, porque este perdeu sua grande função de assenhorar-se da História 33 e dar um sentido ao

29 SARTRE, J.-P. Crítica da Razão Dialética. Trad. Guilherme João de Freitas Teixeira. Rio de Janeiro: DP\&A, 2002. p. 55-56.

30 "Os teóricos de extrema-esquerda acusaram algumas vezes a fenomenologia de ser um idealismo e de afogar a realidade na maré das ideias. Mas se o idealismo é a filosofia sem mal de M. Brunschvicg. se é uma filosofia em que o esforço de assimilação espiritual não se depara jamais com resistências exteriores, em que o sofrimento, a fome, a guerra se diluem em um lento processo de unificação das ideias, então nada é mais injusto do que chamar os fenomenólogos de idealistas. Pelo contrário, há séculos que não se sentia na filosofia uma corrente tão realista. Eles recolocaram o homem no mundo, devolveram o devido peso a suas angústias e seus sofrimentos, e também a suas revoltas. Infelizmente, enquanto o Eu continuar sendo uma estrutura da consciência absoluta, poder-se-á censurar a fenomenologia por ser uma "doutrina escapista", por puxar uma parcela do homem para fora do mundo e desviar desse modo a atenção dos verdadeiros problemas. Parece-nos que essa crítica não tem mais razão de ser ao fazermos do Moi um existente rigorosamente contemporâneo do mundo e cuja existência tem as mesmas características essenciais que o mundo. Sempre me pareceu que uma hipótese de trabalho tão fecunda como o materialismo histórico não requeria absolutamente como fundamento essa absurdidade que é o materialismo metafísico". SARTRE, J.-P. A transcendência do Ego: esboço de uma descrição fenomenológica. Petrópolis, RJ: Vozes, 2013. p. 22. 31 ENGELS, Friedrich. Letter 150, to W. Borgius: London, 25 January, 1894. In: MARX, Karl; ENGELS, Friedrich. Collected Works: Letters 1892-1895. V. 50. London: Lawrence \& Wishart, 2004. p. 266. Contrastar com a seguinte passagem da carta 16, de 1890, para J. Bloch escrita quatro anos antes: "We make our history ourselves but, in the first place, under very definite premises and conditions". In: ENGELS Friedrich. "Letter 16, to Joseph Bloch: London, 21[-22] September, 1890" In: MARX, Karl; ENGELS, Friedrich. Collected Works: Letters 18901892. Vol.49. London: Lawrence \& Wishart, 2001. p. 35.

${ }_{32}$ Do original: [...] men make their own history, but in a given environment by which they are conditioned [...]. SARTRE, J.-P. Critica da Razão Dialética. Trad. Guilherme João de Freitas Teixeira. Rio de Janeiro: DP\&A, 2002. p. 73. Sartre atribui o endereçamento da carta de Engels à Marx, porém parece citar indiretamente a sentença de Engels nessa passagem, visto afirmar na p. 37 ser uma carta de Engels à Plakhanov "por ocasião de um ataque a Bernstein". Contudo, ao verificarmos as Collected Works, onde estão publicadas todas cartas disponiveis de Engels, localizamos somente duas: uma de W. Borgius, de 25 de janeiro de 1894, com a afirmação de Engels praticamente idêntica ao que Sartre lhe atribui; e, outra, para Joseph Bloch, em 21 de setembro de 1890, com a mesma ideia da afirmação citada por Sartre. Observa-se que a nota do editor à tradução da Crítica da Razão Dialética, que estamos usando, atribui erroneamente o endereçamento da carta de 1894 a Hans Starkenburg. A correção para W. Borgius está na nota 329, v. 50, da Collected Works, em que se explica um equívoco editorial de atribuição na edição original alemã.

33 "No século XIX, o marxismo é uma tentativa gigantesca não só de fazer a História, mas de assenhorear-se dela, do ponto de vista prático e teórico, unificando o movimento operário e iluminando a ação do proletariado pelo conhecimento do processo capitalista e da realidade objetiva dos trabalhadores. No termo desse esforço, pela unificação dos explorados e pela redução progressiva do número das classes em luta, a História deve ter, por fim, um sentido para o homem". SARTRE, J.-P. Crítica da Razão Dialética. Trad. Guilherme João de Freitas Teixeira. Rio de Janeiro: DP\&A, 2002. p. 75 
homem. O marxismo abnegou sua função original para dar lugar ao materialismo metafísico, para ceder à burocratização excessiva, fruto de uma incapacidade brutal de compreensão, posse e revolução de seu tempo.

Os conceitos de projeto, situação e possiveis (já presentes na obra $O$ ser e o nada ${ }^{34}$ ) perpassam a virada dialética sartriana e são inseridos nesse novo método. O ser humano segue não sendo apenas um objeto, um espelho, um reflexo inerte da estrutura; é sua relação com ela e o seu projetarse a partir dela que o define. Assim, pode-se compreender que o "homem caracteriza-se, antes de tudo, pela superação de uma situação, por aquilo que consegue fazer do que foi feito dele, embora nunca se reconheça em sua objetivação".35 Esse homem genérico conta com o que ainda não é, com o porvir. A situação objetiva, vivenciada por cada um, é um dado concreto da ação humana que não escolhemos; a prática (práxis) é isto: superar a situação concreta e material por meio de um projeto através das condições possiveis em uma situação. Esse "campo dos possiveis", por sua vez, é perpassado pela História: não é um ente inato e atemporal; é o fruto mais bem trabalhado de uma complexa lógica de práticas materiais, é o resultado da ação do homem no tempo em processos de interiorização da exterioridade e de exteriorização da interioridade em uma situação, até aqui, de escassez.

Essa busca por disciplinas auxiliares é, na verdade, a busca por mediações que nos permitam compreender ao máximo a situação histórica atual em sua real complexidade. Será nula a tentativa, hoje, de compreensão do homem, das relações sociais, da História, sem dispormos da psicanálise e da teoria social, com todas as suas diferenciações, problemas e contradições. De fato, "constatar-se-á que a História é ardilosa", como afirmava Lênin, e que "subestimamos seus ardis". ${ }^{66}$ Para compreender esse ardil, parece-nos, é preciso dispor de um método que englobe o ser e a estrutura, é preciso de um método que seja estrutural e histórico.

Para alcançar esse objetivo, Sartre utiliza o método progressivo-regressivo partindo do singular para o universal; 37 tenta encontrar o homem em seu contexto: "Pedimos à história geral para nos restituir as estruturas da sociedade contemporânea, seus conflitos, suas contradições profundas, e o movimento de conjunto que estas determinam". ${ }^{38}$ Embora continuemos considerando-as como abstratas enquanto conceito (as estruturas), partimos das relações imediatas e materiais para chegarmos a elas e desvelar sua materialidade. Seu objetivo é o de colidir o sujeito com sua época de forma lenta e gradual, sem imediações, tornando-os conflitantes por si em um "vaivém":

O vaivém contribui para enriquecer o objeto com toda a profundidade da História; e determina, na totalização histórica, o lugar ainda vazio do objeto. No entanto, nesse nivel da pesquisa. só conseguimos desvelar uma hierarquia de significações heterogêneas: Madame Bovary, a "feminilidade" de Flaubert, a infância em um prédio do hospital, as contradições da pequena burguesia contemporânea, a evolução da familia, da propriedade etc. Cada uma ilumina a outra, mas sua irredutibilidade cria uma verdadeira descontinuidade entre elas; cada uma serve de enquadramento à precedente, mas a significação envolvida é mais rica do que a significação envolvente. Em poucas palavras, temos

\footnotetext{
34 Conforme pode-se conferir na segunda parte da obra "O Para-si e o ser dos possiveis" e, na quarta parte "Liberdade e facticidade: a situação". SARTRE, J.-P. O ser e o nada - Ensaio de ontologia fenomenológica. 20. ed. Petrópolis: Vozes, 2011.

35 "Afirmamos a especificidade do ato humano que atravessa o meio social, conservando-lhe as determinações, e que transforma o mundo na base de condições dadas. Para nós, o homem caracteriza-se, antes de tudo, pela superação de uma situação, por aquilo que consegue fazer do que foi feito dele, embora nunca se reconheça em sua objetivação. Encontramos essa superação na raiz do humano e. antes de tudo, na necessidade: é ela que associa, por exemplo, a escassez de mulheres nas ilhas Marquesas, como fato estrutural do grupo, à poliandria como instituição matrimonial. Com efeito, essa escassez não é uma simples carência: sob sua forma mais nua, ela expressa uma situação na sociedade e contém já um esforço para superá-la; a conduta mais rudimentar deve ser determinada, de uma só vez, em relação aos fatores reais e presentes que a condicionam e em relação a um certo objeto por vir que ela tenta fazer nascer. $\mathrm{E}$ a isso que damos o nome de projeto". In: SARTRE, J.-P. Crítica da Razão Dialética. Trad. Guilherme João de Freitas Teixeira. Rio de Janeiro: DP\&A, 2002. p. 77.

36 SARTRE, J.-P. Crítica da Razão Dialética. Trad. Guilherme João de Freitas Teixeira. Rio de Janeiro: DP\&A, 2002. p. 92.

"Sartre pretende atingir o movimento dialético da história começando pela vida singular. Contrariamente ao pensamento marxista, que vai das relações de produção às estruturas dos grupos e suas contradições internas, Sartre sustenta que a experiência critica deve partir do imediato - do indivíduo na práxis individual - para encontrar por meio de seus condicionamentos cada vez mais profundos o conjunto de suas ligações mais práticas com os outros, até chegar ao homem histórico". In: CASTRO, Fabio Caprio Leite de. A ética de Sartre. Porto Alegre: Loyola, 2016. p. 103.

38 SARTRE, J.-P. Crítica da Razão Dialética. Trad. Guilherme João de Freitas Teixeira. Rio de Janeiro: DP\&A, 2002. p. 103.
} 
apenas os vestígios do movimento dialético e não o próprio movimento. É então, e somente então, que devemos utilizar o método progressivo: trata-se de reencontrar o movimento de enriquecimento totalizador que engendra cada momento a partir do momento anterior, o impulso que parte das obscuridades vividas para chegar à objetivação final, em poucas palavras, o projeto pelo qual Flaubert, para escapar à pequena burguesia, lançar-se-á, através dos diversos campos de possiveis, em direção à objetivação alienada de si mesmo, além de constituir-se, inelutável e indissoluvelmente, como o autor de Madame Bovary e como esse pequeno-burguês que recusava ser. ${ }^{39}$

\section{Considerações finais}

A virada dialética marca um periodo na obra sartriana de critica ao marxismo vigente de sua época e inaugura sua adesão ao materialismo histórico. O existencialismo é vinculado e fundido ao materialismo histórico de Marx que é, por sua vez, a filosofia insuperável de nosso tempo enquanto esse tempo histórico perdurar. Sartre coloca seu método em curso em O idiota da família ao descrever a vida de Gustave Flaubert; as mediações necessárias se dão pelo auxilio da psicanálise e das teorias sociais; com isso, Sartre almeja uma antropologia que seja, ao mesmo tempo, estrutural e histórica. A infância necessita ser compreendida em sua vivência, uma vez que ela exprime os conflitos estruturais existentes desde as relações materiais mais imediatas até o âmbito mais alto da estrutura social. O método progressivo-regressivo, inspirado em Henry Lefebvre, é a tentativa de conflitar sujeito e estrutura, derivando sinteses totalizantes através de um vaivém. Sartre pretende, com Marx, considerar o homem concreto a partir de sua realidade objetiva.

Sartre alerta que é preciso compreenderse, compreender o outro, existir, agir; para compreender a História em seu movimento, precisamos de um método complexo à altura de seus ardis, precisamos compreender o ser humano em sua relação entre o seu projeto de ser e suas possibilidades dadas pela situação em uma estrutura objetiva. Em suma, é preciso compreender o homem enquanto ser genérico de ponta a ponta. Se percebermos a potência desse método, parece-nos, descobriremos o mundo e voltaremos a agir sobre ele de forma efetiva. Há aqueles que jogam contra essa possibilidade, que gostariam que a História tivesse chegado ao seu fim; para esse pensamento, fundado e conservado no medo, Sartre oferece-nos uma lanterna tão necessária para estes tempos disfóricos ofuscados pela escuridão. É bem verdade que a proposta sartriana dificulta e torna a capacidade de compreensão histórica, em sua totalização, uma tarefa hostil pela sua profundidade e complexidade ao ser posta em prática. Porém, contra aqueles que lutam para conservar o dado, que lutam para frear a mudança, existem os que acreditam no ainda não, no porvir. Resta-nos recomeçar tudo, inventar uma esperança morta, tentar viver.

\section{Referências}

CASTRO, Fabio Caprio Leite de. A ética de Sartre. Porto Alegre: Loyola, 2016

ENGELS, Friedrich. Letter 16, to Joseph Bloch: London, 21[-22] September, 1890. In: MARX, Karl; ENGELS, Friedrich. Collected Works: Letters 1890-1892. London: Lawrence \& Wishart, 2001. v. 49.

ENGELS, Friedrich. Letter 150, to W. Borgius: London, 25 January, 1894. In: MARX, Karl; ENGELS, Friedrich. Collected Works: Letters 1892-1895. Vol. 50. London: Lawrence \& Wishart, 2004.

LEFEBVRE, Henri. De lo rural a lo urbano. 4. ed. Barcelona: Península, 1978.

MÉSZÁROS, I. A obra de Sartre. Trad. Rogério Bettoni. São Paulo: Boitempo, 2012

MARX, Karl. A ideologia alemã: critica da mais recente filosofia alemã em seus representantes Feuerbach, B. Bauer e Stirner, e do socialismo alemão em seus diferentes profetas. São Paulo: Boitempo, 2007

MATTOS, Marcus de Dutra. Sartre e Lukács: Notas para um acerto de contas In: CASTRO, Fabio Caprio Leite de; NORBERTO, Marcelo S. (org.). Sartre Hoje: volume 1. Porto Alegre: $\mathrm{Fi}, 2017$. p. 189-206.

SARTRE, Jean-Paul. A transcendência do Ego. Lisboa: Colibri, 1994.

SARTRE, Jean-Paul. A transcendência do Ego: esboço de uma descrição fenomenológica. Petrópolis, RJ: Vozes, 2013 
SARTRE, Jean-Paul. Critica da Razão Dialética. Trad. Guilherme João de Freitas Teixeira. Rio de Janeiro: DP\&A, 2002.

SARTRE, Jean-Paul. Critique de la Raison dialectique. Tome I - Théorie des ensembles pratiques, précédé de Questions de méthode. Paris: Gallimard, 1960.

SARTRE, Jean-Paul. La Transcendance de l'Ego: Esquisse d'une Description Phénoménologique. Paris: Librairie Philosophique J. Vrin, 2003.

SARTRE, Jean-Paul. L'être et le néant: essai d'ontologie phénoménologique. Paris: Gallimard, 1969

SARTRE, Jean-Paul. L'Idiot de la Famille - Gustave Flaubert de 1821 à 1857. Vol. I. Paris: Gallimard, 1988 (1971).

SARTRE, Jean-Paul. O idiota da familia, v1. Trad. Julia da Rosa Simões. Porto Alegre: L\&PM, 2013.

SARTRE, Jean-Paul. O ser e o nada - Ensaio de ontologia fenomenológica. 20. ed. Petrópolis: Vozes, 2011.

SARTRE, Jean-Paul. Questão de método. São Paulo: Difusão Europeia do Livro, 1968.

\section{Marcus de Dutra Mattos}

Doutorando no Programa de Pós-Graduação em Filosofia da Pontifícia Universidade Católica do Rio Grande do Sul (PUCRS, Porto Alegre, RS, Brasil); bolsista Coordenação de Aperfeiçoamento de Pessoal de Nivel Superior (Capes).

\section{Endereço para correspondência}

Marcus de Dutra Mattos

Pontificia Universidade Católica do Rio Grande do Sul

Av. Ipiranga, 6.681, Prédio 4, sala 2

Partenon 97010-082

Porto Alegre, RS, Brasil 